\title{
Role of mast cells in oestradiol effects on the uterus of ovariectomized rats
}

\author{
A. G. Gunin and A. A. Sharov \\ Department of Histology, Medical Institute of Chuvash State University, Moscowski Avenue, 15, \\ Cheboksary 428015, Russia
}

\begin{abstract}
The role of mast cells and their main secretory products in the effects of oestradiol on the uterus was investigated. Ovariectomized rats were treated with a single injection of oestradiol (10 $\mu \mathrm{g}$ per rat, i.m.) or vehicle together with drugs affecting the activity of mast cells, cromoglycate (10 mg per rat, i.m.), which diminishes the degranulation of mast cells, or compound $48 / 80(0.5 \mathrm{mg}$ per rat, i.m.), which enhances this process. Oestradiol or vehicle was also administered with two important secretory products of mast cells, heparin $(0.4 \mathrm{mg}$ per rat, i.m.) or histamine ( $2 \mathrm{mg}$ per rat, i.m.). All drugs were injected simultaneously with oestradiol (first injection) and then every $6 \mathrm{~h}$ until the animals were killed. Observations were performed at 24,36 and $48 \mathrm{~h}$ after oestradiol or vehicle injection. The condition of mast cells was determined by the percentage of degranulated mast cells in sections stained with toluidine blue. Oestradiol-induced effects in the uterus were estimated by the mitotic index, proliferating cell nuclear antigen-labelling index, DNA content, volumes of cells, nuclei and nucleoli in the luminal epithelium, glandular epithelium and stroma cells of the endometrium. Cromoglycate treatment resulted in a decrease in both mast cell degranulation and all examined oestradiol effects in the uterus at all periods of observation. Compound 48/80 increased mast cell degranulation and expression of one aspect of oestradiol effects on the volumes of cell compartments. Histamine or heparin led to a marked increase in the cell, nucleus and nucleolus volumes in all uterine structures. However, heparin produced a depression in proliferation, whereas histamine had a weak transient stimulating action on this process. No effects of the protocols were found in the absence of oestradiol treatment. These results suggest that mast cells are involved in the realization of oestrogen action, including the stimulation of cell growth and proliferation in the uterus, and that the effect of mast cells is mediated by both histamine and heparin.
\end{abstract}

\section{Introduction}

Many studies have investigated the inter-relationships between mast cells and the action of oestrogens on the uterus. Oestrogens increase the functional activity of mast cells (Iversen, 1964; Maraspin and Bo, 1971; Brandon and Evans, 1983; Huang et al., 1995; Jeziorska et al., 1995) and increase the concentration of histamine in the uterus (McKercher et al., 1973; Hine et al., 1985; Gunin, 1989; Cocchiara et al., 1992). Although contradictory data have also been obtained (Szego, 1965; Wordinger et al., 1985; Padilla et al., 1990; Drudy et al., 1991; Gosden et al., 1993), it has been suggested that mast cells play a role in the realization of oestradiol effects in the uterus.

Mast cells and histamine have been shown to be involved in the development of several oestrogen-like (Spaziani, 1963; Pankova et al., 1985) and oestrogen-induced effects (Mohla and Prasad, 1969; Castro Vazquez et al., 1976; Marshall and Senior,

Received 22 August 1997.
1986) in the uterus, although some oestrogen-dependent and oestrogen-like processes remain unaffected (Brody et al., 1975; Clark et al., 1977; Terada et al., 1985; Wordinger et al., 1985). There are no data demonstrating the role of mast cells in oestrogen-induced proliferation and cell growth in the uterus, or in oestrogen action on the uterus under blockade of functional activity of mast cells. Nor are there data about involvement of histamine and heparin, the two most important mast cell secretory products, in oestrogen-induced cell growth and division in the uterus. Hence, a role of mast cells in the action of oestradiol on the uterus remains unclear. The present study was designed to investigate the role of mast cells and their main secretory products in the realization of the most important oestradiol effects, including the activation of growth and proliferation in the uterus.

Some of the data reported here on the effects of heparin have been published (Gunin, 1997); however, it was considered useful to include those results in this paper to allow comparison between heparin and histamine action and better understanding of the role of mast cells in oestradiol effects on the uterus. 


\section{Materials and Methods}

\section{Animals}

All procedures were performed in accordance with the Guidelines on the Handling and Training of Laboratory Animals (Universities Federation for Animal Welfare, Potters Bar, Herts).

White female mature unmated rats weighing $150-180 \mathrm{~g}$ were obtained from Central Nursery for laboratory animals of the Russian Academy of Medical Sciences (Moscow), and were housed under the same conditions with free access to water and food. One month before the experiment, all the rats were ovariectomized under anaesthesia with ketamine and droperidol $(7 \mathrm{mg}$ per rat; $0.1 \mathrm{mg}$ per rat, i.m., respectively; Gedeon Richter, Budapest).

\section{Treatment schedule}

Two experimental series were designed. In Expt 1, the rats were treated with oestradiol together with drugs affecting mast cell degranulation, to compare the action of oestradiol on the uterus with a background of either high or low activity of mast cells. Disodium cromoglycate was chosen as a drug that stabilizes mast cells and prevents their degranulation (Tainsh et al., 1991) and compound $48 / 80$ was chosen as an agent that produces a strong degranulation of mast cells (Barker, 1967; Josefsson, 1968). In Expt 2, rats were treated with oestradiol together with the two most important secretory products of mast cells: heparin and histamine.

The rats were treated with a single injection of oestradiol dipropionate (10 $\mu \mathrm{g}$ per rat; i.m.; Minmedprom, Rostov-Don) or vehicle (olive oil; $0.1 \mathrm{ml}$ per rat, i.m.) together with injections of disodium cromoglycate $(10 \mathrm{mg}$ per rat, i.m., Fisons Ltd, Loughborough) or compound 48/80 (0.5 mg per rat, i.m., Sigma Chemical Co., St Louis, MO), or heparin (molecular weight approximately $16 \mathrm{kDa} ; 0.4 \mathrm{mg}$ (50 iu) per rat, i.m.; Minmedprom, Moscow), or histamine dihydrochloride (2 $\mathrm{mg}$ per rat, i.m.; Merck, Darmstadt), or saline vehicle $(0.15 \mathrm{~mol}$ sodium chloride $\mathrm{l}^{-1}, 0.1 \mathrm{ml}$ per rat, i.m.).

All drugs were dissolved in saline and injected simultaneously with oestradiol or olive oil (first injection) and then every $6 \mathrm{~h}$ until the animals were killed. Observations were made at 24,36 and $48 \mathrm{~h}$ after oestradiol or olive oil injection. There were ten rats per oestradiol treated group, and five rats per olive oil treated group.

\section{Manipulations with tissue specimens}

The middle segments of uterine horns were removed from animals under deep ether anaesthesia and placed immediately in fixing fluids. The animals were then killed by exsanguination. Part of the tissue specimens from each animal was fixed in Carnoy's fluid ( $1.5 \mathrm{~h}$ at room temperature) and another was fixed in Bouin's fluid ( $24 \mathrm{~h}$ at room temperature). All material was then dehydrated and embedded in paraffin wax and transverse sections $(5-6 \mu \mathrm{m})$ were prepared.

\section{Analysis of mast cells}

The effectiveness of action of the drugs on mast cells was estimated by calculating the percentage of degranulated mast cells in three uterine regions: the endometrium, myometrium and mesometrial triangle (Gibbons and Chang, 1972). For this, sections fixed in Bouin's fluid were stained with $0.1 \%(\mathrm{w} / \mathrm{v})$ toluidine blue in $40 \%(\mathrm{v} / \mathrm{v})$ ethanol for $15 \mathrm{~min}$. Degranulated and non-degranulated mast cells in each compartment were counted separately under a light microscope. Mast cells with more then three granules outside of the cell shape or with empty cavities in the cytoplasm were considered as degranulated (Gibbons and Chang, 1972). The counting procedure was performed in each third section in a series of sections and at least ten sections were viewed for each rat.

\section{Analysis of oestradiol effects}

The action of oestradiol on the uterus was assessed on the basis of mitotic index, proliferating cell nuclear antigen (PCNA)-labelling index, DNA content, and the volumes of cells, nuclei and nucleoli. These parameters reflect two of the most important aspects of oestrogen action on the uterus: tissue proliferation and growth.

Mitotic index. Mitotic index was determined for the luminal epithelium, glandular epithelium and stroma cells of the endometrium in the sections prepared from tissue fixed in Carnoy's fluid and stained with iron haematoxylin (Gunin, 1996). Mitotic index is the proportion of cells in any phase of mitosis out of the total number of cells examined. At least 3000 cells were viewed in each structure for each animal.

PCNA immunoreactivity, PCNA-labelling index. Sections from tissue fixed in Bouin's fluid were hydrated, and nonspecific binding was blocked with $1 \%$ normal goat serum in Tris-buffered saline (TBS) pH 7.2-7.6 for $\mathrm{I} h$. Tissues were incubated for $2 \mathrm{~h}$ with primary anti-PCNA mouse monoclonal antibody (DAKO, Glostrup) diluted 1:50 in TBS with $1 \%$ normal goat serum and with $0.1 \%(v / v)$ Triton $X-100$. After rinsing in TBS for $3 \times 5 \mathrm{~min}$, sections were incubated for $1 \mathrm{~h}$ with secondary goat anti-mouse immunoglobulin $G$ antibody conjugated with alkaline phosphatase (Jackson ImmunoResearch Laboratories Inc., West Grove, PA) diluted 1:50 in TBS with $0.1 \%$ Triton $X-100$, and then rinsed in TBS for $3 \times 5 \mathrm{~min}$. Alkaline phosphatase activity was revealed using naphthol AS-BI-phosphate and new fuchsin as chromogens. All procedures were performed at room temperature. In control sections, the primary antibody was replaced with normal goat serum. The slides were examined under a light microscope at $\times 400-1000$ magnification. Positive staining by primary antibody was indicated by a red precipitate localized in the nuclei. PCNA-labelling index was determined in the luminal epithelium, glandular epithelium and stroma cells of endometrium by counting the proportion of PCNA-positive cells of the total number of cells examined. At least 3000 cells in each structure were examined for each animal.

DNA content. DNA content in luminal epithelium, glandular epithelium and stroma cells of the endometrium was determined by Feulgen's reaction in sections prepared from tissue fixed in Carnoy's fluid. Feulgen staining was quantified by photometric measurement of light absorbance $(D)$ for the 
nuclei. Photometry was performed using a light microscope and FMEL-1A microspectrophotometer (LOMO, St Petersburg) by measuring the intensity of light passed through the equal areas occupied by the nucleus $(F)$ and occupied by the structures other than nucleus $\left(F_{0}\right)$. Absorbance (light absorption) was calculated from the formula: $D=1 g\left(F_{\mathrm{o}} / F\right)$, multiplied by the nucleus volume, and the DNA content was expressed in arbitrary units. At least 100 nuclei were analysed for each structure in each rat. All procedures for evaluation of DNA content were made as described by Gunin (1996).

Volumes of cells, nuclei and nucleoli. These volumes were determined in the luminal epithelium, glandular epithelium and the cells of endometrial stroma in uterine sections fixed in

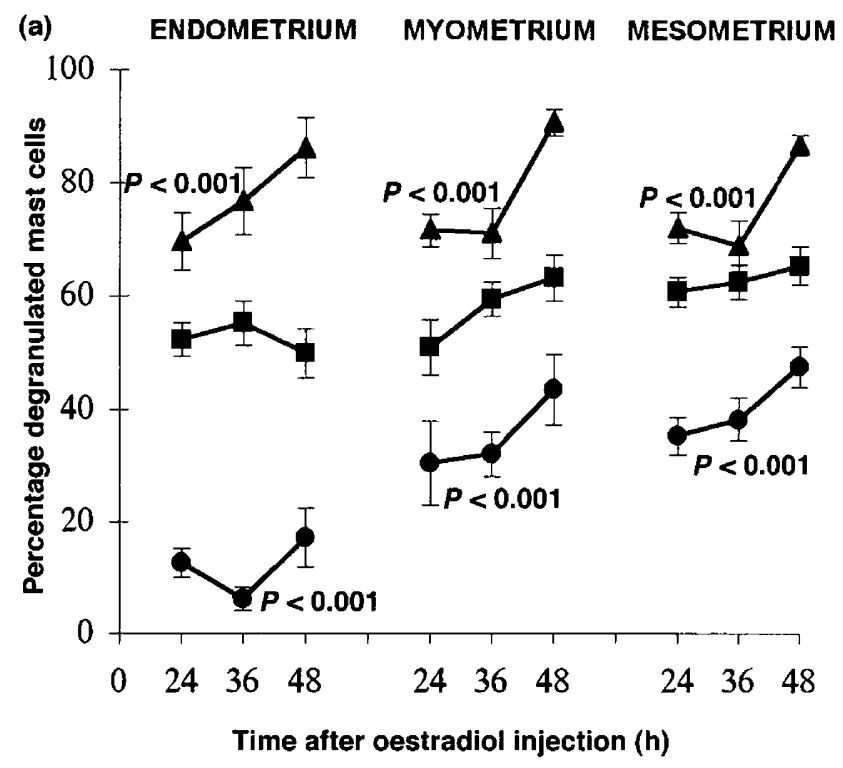

(b)

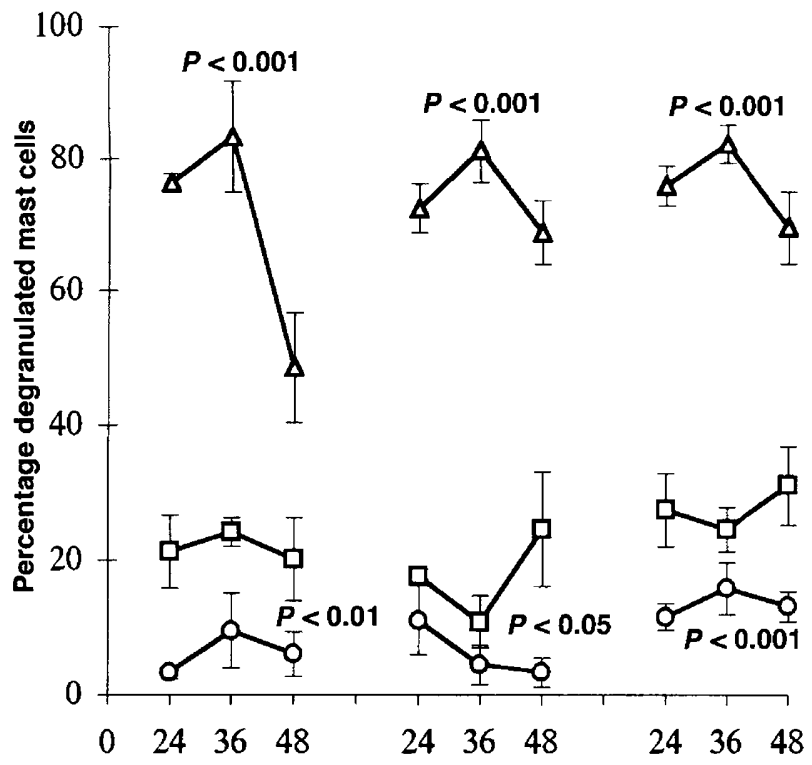

Time after olive oil injection (h)
Carnoy's fluid and stained with iron haematoxylin. The calculation of the volumes was based on results of morphometry performed using an ocular micrometer and light microscope. The sizes of cells, nuclei and nucleoli were determined and the volumes calculated, as described by Gunin (1996). At least 100 measurements were performed for each object examined from each animal.

\section{Statistical analysis}

Arithmetic means and standard errors were calculated in each data group. The significance of differences was evaluated by Student's $t$ test. The significance of the influence of the treatments at different time points after oestradiol or vehicle injection was determined by two-way analysis of variance.

\section{Results}

\section{Condition of mast cells}

Treatment with oestradiol caused an intensive degranulation of mast cells for all the uterine compartments, compared with those for animals treated with olive oil (Fig. 1). All statistical comparisons among corresponding data from control rats treated with oestradiol and olive oil with saline were significant $(P<0.05$, Student's $t$ test). However, there are no significant differences among the data from different time groups. Injections of cromoglycate to rats treated and untreated with oestradiol led to a decrease in the proportion of degranulated mast cells in all the uterine compartments at all points of observation (Fig. 1). In contrast, treatment with compound $48 / 80$ enhanced mast cell degranulation in rats that received either oestradiol or olive oil. In this case, almost all results were significant (Fig. 1). Two-way analysis of variance showed that cromoglycate or compound $48 / 80$ markedly increased action on mast cells degranulation (Fig. 1).

\section{Oestradiol effects under treatment with cromoglycate}

Treatment with cromoglycate resulted in a decrease in all uterine parameters including mitotic and PCNA-labelling indices, DNA content, and cell, nucleus and nucleolus volumes in all structures, compared with those of rats treated with

Fig. 1. The effects of cromoglycate and compound $48 / 80$ on mast cell degranulation in the uteri of ovariectomized rats treated and untreated with oestradiol. Data from rats treated with (a) oestradiol (a single injection, $10 \mu \mathrm{g}$ per rat, i.m.) or (b) vehicle (olive oil, $0.1 \mathrm{ml}$ per rat, i.m.) together with cromoglycate $(\bigcirc, \bigcirc)$ or compound $48 / 80(\boldsymbol{\Lambda}, \triangle)$ are compared with the data from control rats treated with oestradiol (ם) or olive oil $(\square)$ together with saline. Cromoglycate disodium (10 mg per rat, i.m.) or compound $48 / 80$ (0.5 mg per rat, i.m.) was injected at intervals of $6 \mathrm{~h}$ after oestradiol injection. Measurements were made at 24,36 and $48 \mathrm{~h}$ after oestradiol or olive oil injection. Values are means \pm SEM. The significance of the influence of cromoglycate or compound $48 / 80$ on the mast cell degranulation in the uterus of ovariectomized rats at 24,36 and $48 \mathrm{~h}$ after oestradiol or olive oil injection (two-way analysis of variance) is indicated. 
oestradiol (Fig. 2). However, differences were not so marked and only some were significant.

\section{Oestradiol effects under treatment with compound $48 / 80$}

In rats treated with oestradiol plus compound $48 / 80$, all data for cell, nucleus and nucleolus volumes in all structures at all time-points were higher than in control animals (Fig. 2). Most of these differences were significant. The parameters reflecting the proliferative component of oestradiol action (mitotic index, PCNA-labelling index and DNA content) did not change after treatment with compound $48 / 80$ (Fig. 2). However, the mitotic index for glandular epithelium at $36 \mathrm{~h}$ and the DNA content in stroma cells at 24 and $48 \mathrm{~h}$ were significantly greater than control values.

\section{Oestradiol effects under treatment with histamine or heparin}

Treatment with oestradiol plus histamine led to an increase in all tested parameters in the uterus (Fig. 3). Only the mitotic indices for luminal epithelium at $48 \mathrm{~h}$ and for glandular epithelium and stroma cells at 36 and $48 \mathrm{~h}$ after oestradiol injection were lower than in controls.

Treatment with oestradiol plus heparin led to a reduction in mitotic activity and DNA content for all uterine structures examined compared with control oestradiol-treated rats (Fig. 3 ). In the luminal and glandular epithelia of rats treated with oestradiol and heparin, the PCNA-labelling index was almost unchanged at all time points compared with that of oestradioltreated animals. In the stroma cells for rats treated with oestradiol plus heparin, the PCNA-labelling index was higher than in rats treated with oestradiol only at all time points (Fig. 3). Cell, nucleus and nucleolus volumes in all uterine structures at all time points were much higher after treatment with oestradiol plus heparin, and most comparisons were statistically significant (Fig. 3). In comparison with histamine, the effect of heparin on volume parameters is similar but more marked. In contrast to histamine, which stimulates oestradiol-induced proliferative activity, heparin produces a decrease in these reactions.

In ovariectomized rats that were not treated with oestradiol, none of the treatment protocols used produced any significant changes compared with animals treated with olive oil. The parameters of rats treated with olive oil and saline $24 \mathrm{~h}$ after olive oil injection are presented (Figs 2 and 3 at $0 \mathrm{~h}$ ). The data of rats treated with olive oil and cromoglycate, compound $48 / 80$, histamine, heparin, or saline were very similar (data not shown).

Treatment with cromoglycate results in a decrease in mast ceil degranulation and all tested oestradiol effects in the uterus. The action of cromoglycate on cell proliferation and growth is approximately equal. In contrast, compound 48/80 increases mast cell degranulation and expression of one aspect of oestradiol effects on cell growth. Histamine and heparin also affect the action of oestradiol on the uterus. Their effects on volume parameters are similar and include marked increases in cell, nucleus and nucleolus volumes in all the uterine structures. However, heparin produces a marked reduction of proliferation, whereas histamine has a weak transient stimulating action on oestradiol-induced proliferative processes in the uterus. No effect of any of the protocols used was found in the absence of oestradiol treatment.

\section{Discussion}

The present study was designed so that oestradiol could act on the uterus in the conditions of blockade or activation of mast cells. For this purpose two drugs known to modulate the functional activity of mast cells were used: disodium cromoglycate, which decreases mast cell secretion (Tainsh et al., 1991), and compound 48/80, which stimulates mast cell degranulation (Barker, 1967; Josefsson, 1968). The effectiveness of action on uterine mast cells of both of these drugs has been proved by previous investigations (Barker, 1967; Josefsson, 1968; Tainsh et al., 1991). Treatment with cromoglycate also led to a decrease in the proportion of degranulated mast cells in all uterine compartments, whereas compound $48 / 80$ had the opposite effect. Therefore, oestradiol injected together with either cromoglycate or compound $48 / 80$ acted with the background of diminished or abolished, respectively, activity of mast cells.

The results of the present study and those of other workers (Westin, 1955; Gibbons and Chang, 1972; Popova, 1989) showed that oestradiol produces an increase in mast cell degranulation compared with untreated controls. However, the mechanism by which oestradiol acts on the mast cells has not been established.

The three uterine structures, luminal epithelium, glandular epithelium and stroma cells, were chosen for study because they have different numbers of oestrogen receptors (Janssens et al., 1983). In addition, epithelial and stromal tissues have different embryonic sources and, therefore, may be expected to respond differently to treatment.

In the present study, two aspects of oestradiol action on the uterus were analysed. The first of these is an enhancement of proliferative activity. It is known that oestrogen hormones reduce the duration of all the periods of the cell cycle and drive cells from the Go to the GI phase (Quarmby and Korach, 1984; Evans et al., 1990; Galand and de Maertelaer, 1992). As a result, the number of cells passing through and remaining in the GI and $S$ phases, the number of PCNA-labelled cells and the number of dividing cells are increased (Quarmby and Korach, 1984; Evans et al., 1990; Galand and de Maertelaer, 1992; Rumpel et al,, 1995). PCNA is an auxiliary protein of DNA polymerase $\delta$ which is required for DNA synthesis and repair, and is present in cells in the G1, S, G2 and M phases of the cell cycle (Woods et al., 1991; Sawtell et al, 1995). The other important aspect of oestrogen action on the uterus is an increase of cell growth, and this was analysed by measurement of the volume of cells, their nuclei and nucleoli. It is clear that an enlargement in the volumes of cells, nuclei and nucleoli is caused by an activating influence of this hormone on numerous intracellular processes such as an intensification of transcription (Aronica and Katzenellenbogen, 1993), including that of the nucleolar organizer region (Brantley and Whelly, 1990), an increase of the RNA content and in the products of RNA processing in the nucleus (O'Malley and Means, 1974; Brantley and Whelly, 1990) and an activation of biosynthetic reactions 

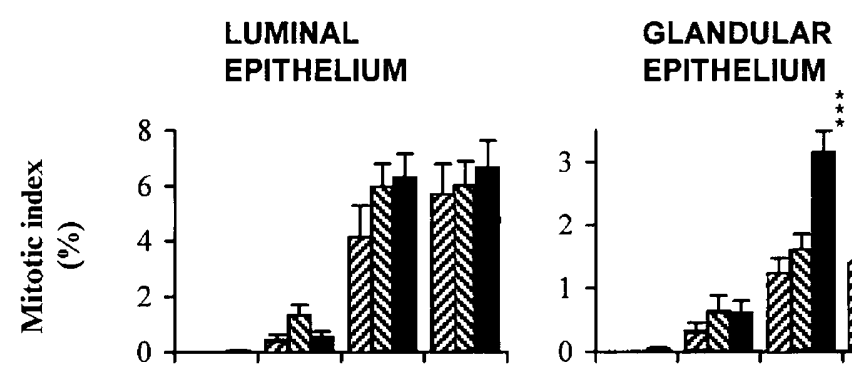

STROMA

CELLS
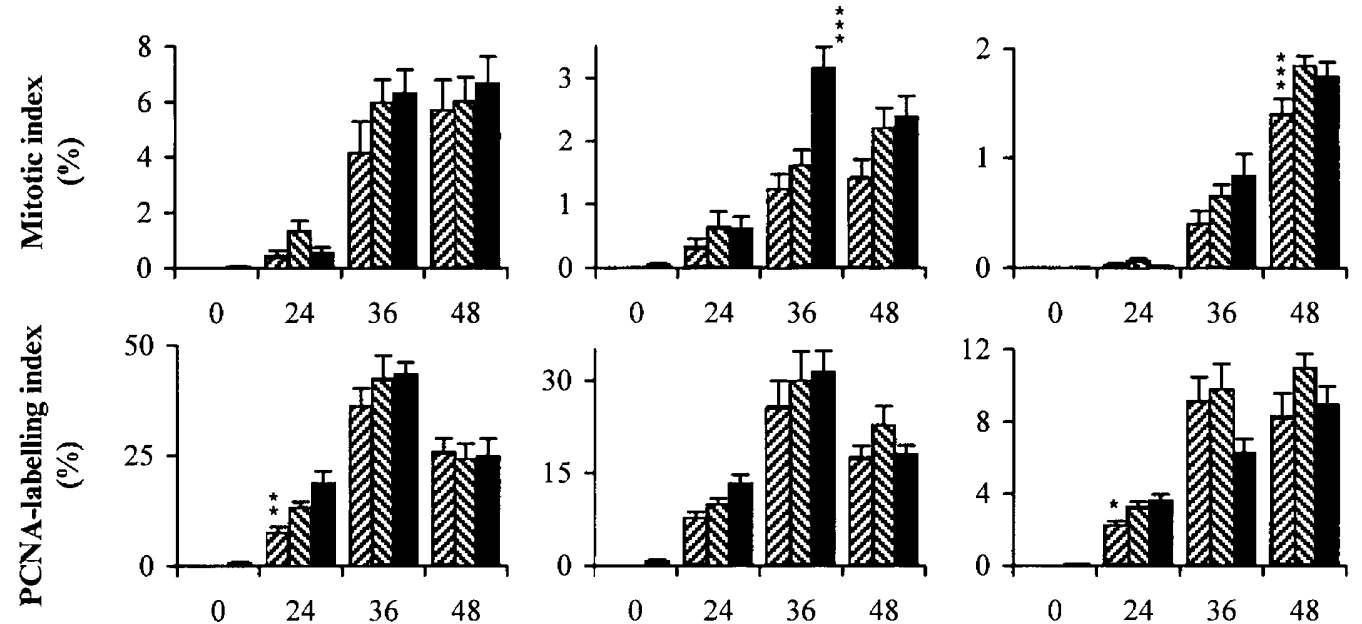

$\begin{array}{llll}0 & 24 & 36 & 48\end{array}$
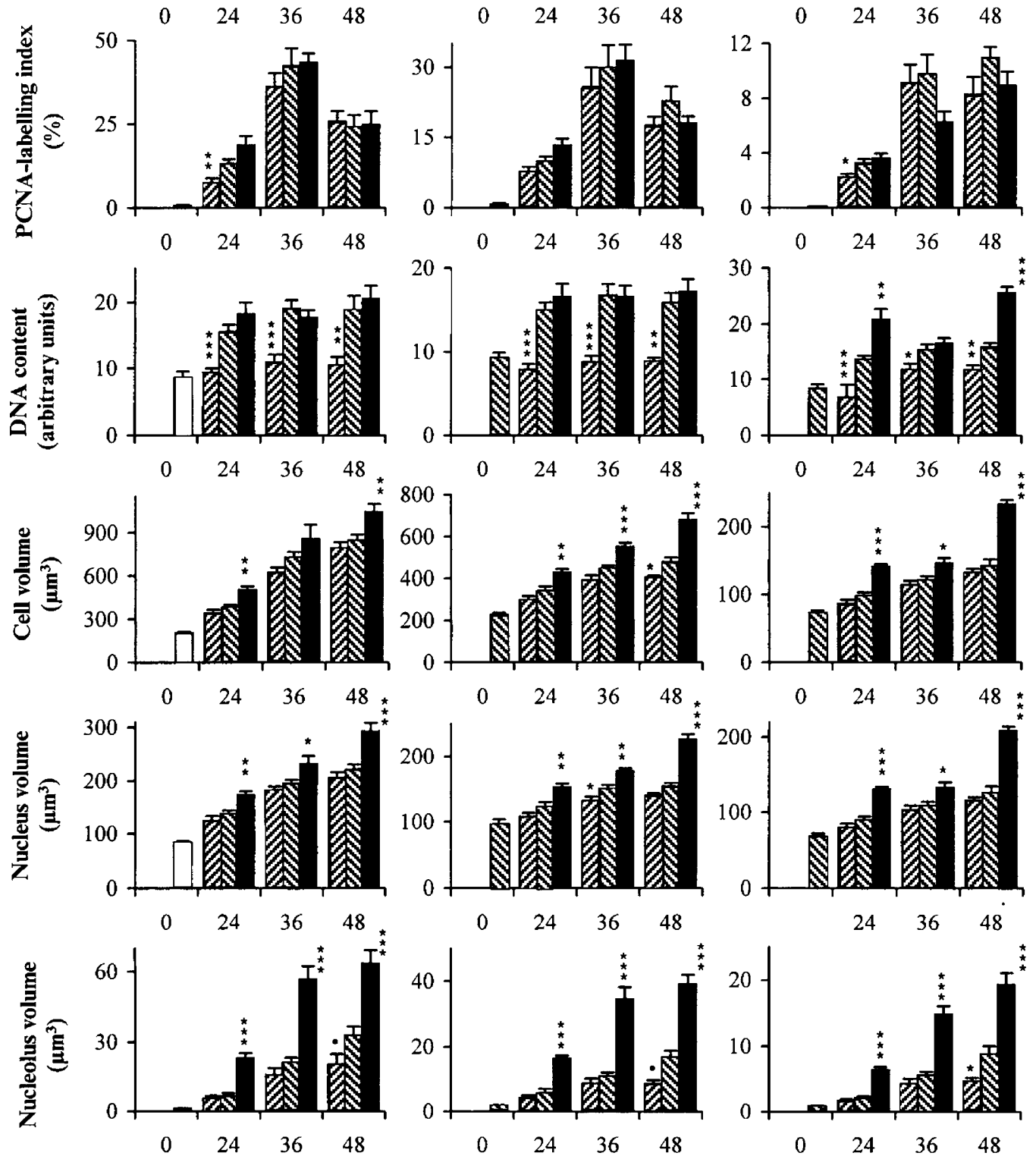

\section{Time after oestradiol injection (h)}

Fig. 2. The effect of treatment with cromoglycate or compound $48 / 80$ on oestradiol-induced increases in mitotic indices, proliferating cell nuclear antigen (PCNA)-labelling indices, DNA content, and the volumes of cells, nuclei and nucleoli in the uteri of ovariectomized rats. Data from rats treated with oestradiol together with cromoglycate (EZ) or compound 48/80 ( $\mathbf{\square}$ ) are compared with data from control rats treated with oestradiol and saline $(\mathbb{\Xi})$. Oestradiol was administered singly (10 $\mu \mathrm{g}$ per rat, i.m.). Cromoglycate disodium (I0 mg per rat, i.m.) or compound $48 / 80(0.5 \mathrm{mg}$ per rat, i.m.) was injected at intervals of $6 \mathrm{~h}$ after oestradiol injection. Measurements were made at 24,36 and $48 \mathrm{~h}$ after oestradiol injection. Values are means $\pm \mathrm{sl}$. Data from rats treated with olive oil and saline at $24 \mathrm{~h}$ after oil injection are shown at $0 \mathrm{~h}(\square)$. No changes were observed among data from all olive oil-treated time-groups. ${ }^{*} P<0.05$; ${ }^{* *} P<0.01 ;{ }^{* * *} P<0.001$; Student's $t$ test, compared with the data from rats treated with oestradiol. 

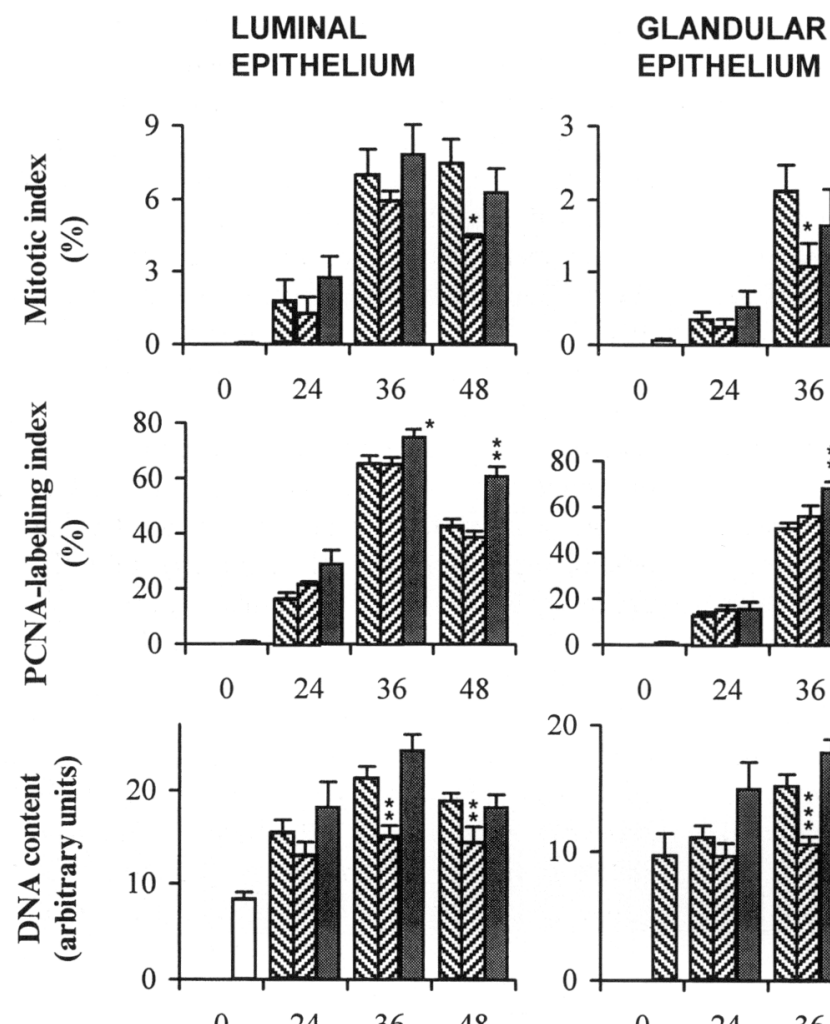

STROMA

CELLS
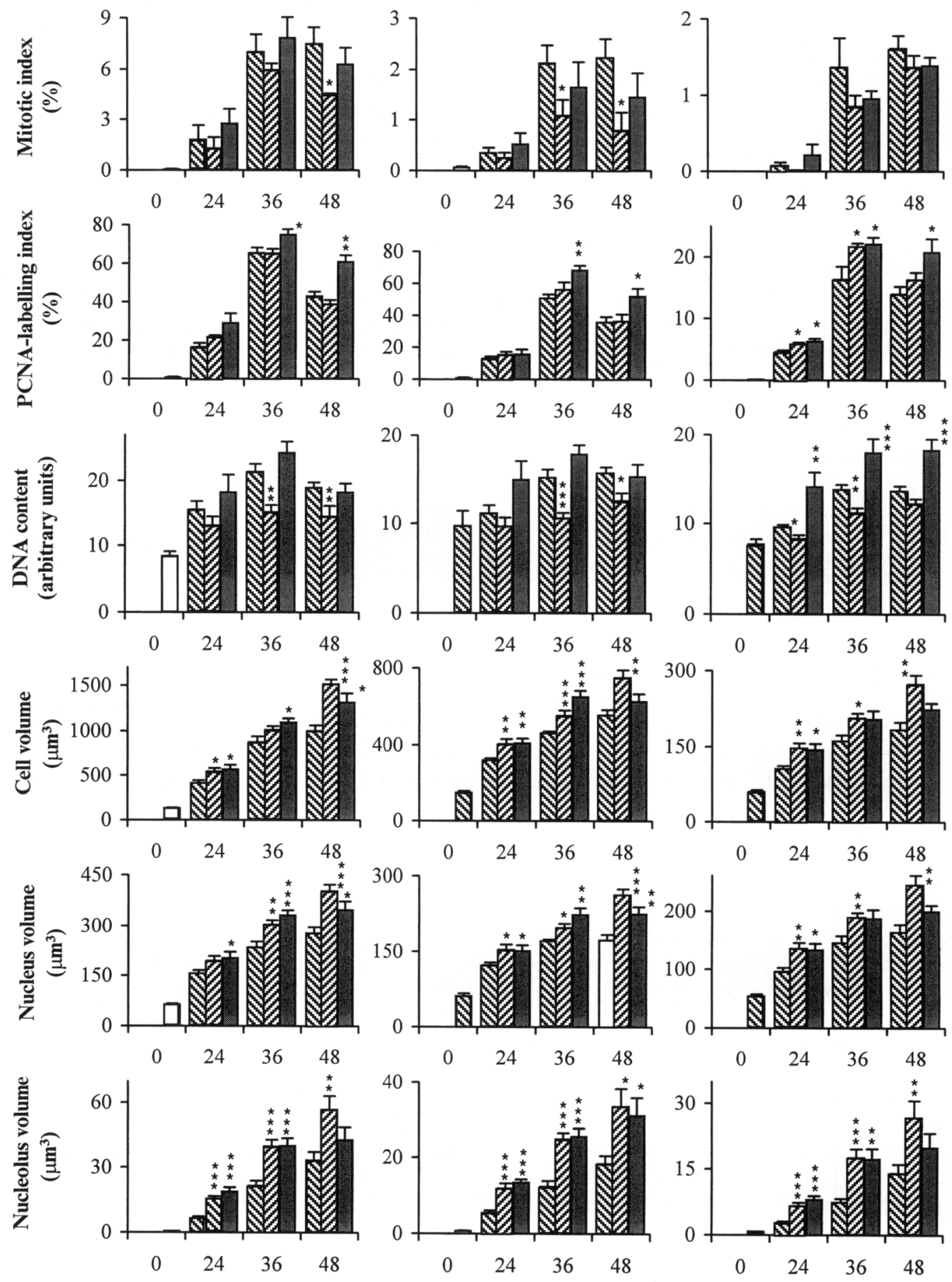

Time after oestradiol injection (h)

Fig. 3. The effects of treatment with histamine or heparin on oestradiol-induced increase in mitotic indices, proliferating cell nuclear antigen (PCNA)-labelling indices, DNA content, and volumes of cells, nuclei and nucleoli in the uteri of ovariectomized rats. Data from rats treated with oestradiol together with histamine ( $\mathbf{\square}$ ) or heparin (Z) are compared with the data from control rats treated with oestradiol and saline $(S)$. Oestradiol was administered singly (10 $\mu \mathrm{g}$ per rat, i.m.). Histamine dihydrochloride (2 mg per rat, i.m.) or heparin (0.4 mg (50 iu) per rat, i.m.) was injected at intervals of $6 \mathrm{~h}$ after oestradiol injection. Measurements were made at 24,36 and $48 \mathrm{~h}$ after oestradiol injection. Values are means $\pm \mathrm{sfm}$. Data from rats treated with olive oil and saline at $24 \mathrm{~h}$ after oil injection are shown at $\mathrm{O} h(\Pi)$. No changes were observed among data from all olive oil-treated time-groups. ${ }^{*} P<0.05 ; * * P<0.01{ }^{* * *} P<0.001$; Student's + test, compared with the data from rats treated with oestradiol. 
in the cytoplasm (Abdi Dezfuli and Poyser, 1993). The sizes of these structures are closely and positively correlated with their functional activify (Martin et al., 1973; Lavia et al., 1985; Murray, 1992) and reflect an intensity of oestrogen influence on the uterus. Therefore, the changes in these parameters observed in the present study after different treatment protocols are probably caused by changes in the above mentioned processes in the uterine cells. All the treatment protocols, except injection of heparin, led to one-directional shifts in proliferative parameters. However, heparin produced a decrease in DNA concentration and in the mitotic indices and a slight increase in PCNA-labelling index. Since the mitotic index reflects the number of cells in the $\mathrm{M}$ phase and the DNA content reflects the number of cells in the S, G2 and M phases, these data indicate a decrease in the number of cells passing through the $\mathrm{S}$ and $\mathrm{M}$ phases. However, PCNA presents in cells in the G1, S, G2 and M phases but not in cells in the G0 phase (Woods et al., 1991; Sawtell et al., 1995), indicating that the number of cyclic cells in the GI, S, G2 and S phases is increased. Therefore, heparin treatment appears to prevent the passing of cells from the GI to the $S$ phase of the cell cycle, causing these cells to remain in the GI phase. It is probable that uterine cells in the GI phase are able to prolong their biosynthetic processes and accumulate a greater variety of products after increases in the volumes of the cell, nucleus and nucleolus (Gunin, 1997).

Treatment with oestradiol against a background of diminished mast cell activity (caused by injection of cromoglycate) led to a decrease in proliferative activity and volume parameters of cells. This finding suggests that mast cells are involved in oestradiol action on the uterus and require oestrogens to realize their action fully. Treatment with oestradiol against a background of increased mast cell degranulation (caused by injection of compound $48 / 80$ ) produced an increase in volume parameters, but a less marked effect on the proliferative component of oestradiol action. Hence, this protocol supports or provides oestrogen action only partially. These results support the contention that proliferative and growth processes are controlled by different regulatory pathways and, therefore, may be regulated independently (Janssens et al., 1983; Cheng et al., 1985).

Experiments with histamine and heparin help to define and explain mechanisms involved in effects obtained under treatment with cromoglycate or compound $48 / 80$. Both histamine and heparin induce a marked increase in cell, nucleus and nucleolus volumes in all uterine structures. However, heparin produces a decrease in proliferation, whereas histamine has a weak transient stimulating action on oestradiol-induced proliferative processes in the uterus. Since histamine and heparin have the same effect on the volume parameters, and cromoglycate and compound $48 / 80$ have the same effect on oestradiol action, it may be concluded that an effect of mast cells on the oestradiol-induced increase in volumes of the cell compartments in all the uterine structures is realized via synergistic action of histamine and heparin. The situation with proliferative activity is more complex. Heparin diminishes, histamine has a weak stimulating action and compound $48 / 80$ has almost no affect on oestradiol-induced proliferative processes. It is possible that the effect of mast cells on proliferation depends on the action of both histamine and heparin; however, their effects are opposite and, therefore, their combined influence produces almost no result. Experiments with cromoglycate, which showed that uterine parameters analysed are diminished under treatment with this drug, do suggest that mast cells are also involved in the development of oestrogen-induced proliferation in the uterine tissues.

The mechanisms by which histamine and heparin bring about their action are unclear. It may be that histamine realises its action through $\mathrm{H}_{2}$-histamine receptors, which are known to be present in the uterus (Goyal and Verma, 1982; Pankova et al., 1985). In addition, numerous processes involved in a regulation of proliferative activity are mediated by this type of histamine receptor (Pankova et al., 1985; Gunin, 1989). The action of heparin may be realized via binding with heparinbinding epidermal growth factor-like growth factor which is probably involved in oestrogen action in the uterus (Wang et al. 1994; Zhang et al., 1994), or via inhibiting the activity of different enzymes required for DNA synthesis (Cook and Aikawa, 1973; Fisher and Blumental, 1982). Heparin has been shown to bind oestrogen receptors in vitro (Molinari et al., 1977; Tong et al. 1983) and it is possible that this property is present in vivo. Mast cells, heparin and histamine probably realize their own actions on the oestradiol effects via changes in the mechanism of oestrogen action in the uterus, because in ovariectomized rats untreated with oestradiol, no changes were found under the treatments.

In conclusion, the present study showed that mast cells are involved in the realization of oestrogen action, including a stimulation of cell growth and proliferation in the uterus, and that the effect of mast cells is mediated by both histamine and heparin. However, the mechanisms of mast cells, histamine and heparin action are not so clear. Moreover, other mast cell-derived cytokines not investigated in the present study may also be involved in realization of oestradiol effects in the uterus. Further experiments are needed to elucidate the interrelationships between mast cells and oestrogen hormones in the uterus.

\section{References}

Abdi Dezfuli F and Poyser NL (1993) Hormonal control of proteins synthesized and secreted by guinea-pig endometrium Journal of Reproduction and Fertility $97 \quad 179-188$

Aronica SM and Katzenellenbogen BS (1993) Stimulation of estrogen receptormediated transcription and alteration in the phosphorylation state of the rat uterine estrogen receptor by estrogen, cyclic adenosine monophosphate, and insulin-like growth factor 1 Molecular Endocrinology 7 743-752

Barker KL (1967) Cofactor induced synthesis of D-glucose-6-phosphate: NADP oxidoreductase in the uterus Endocrinology $81791-797$

Brandon JM and Evans JE (1983) Changes in uterine mast cells during the estrous cycle in the Syrian hamster American Journal of Anatomy 167 241-247

Brantley KM and Whelly SM (1990) Effect of estrogen on the elongation rate and number of RNA chains being synthesized in uterine nucleoli Journal of Steroid Biochemistry and Molecular Biology 35 367-375

Brody MJ, Edvinsson L and Sjoberg NO (1975) Preservation of estrogen-induced increase of uterine blood volume following catecholamine and mast cell histamine depletion Proceedings of the Society for Experimenta! Biology and Medicine 149 120-123

Castro Vazquez A, Gomez E, De Carli DN and Rosner JM (1976) Further evidence for histamine facilitating oestrogen action in the uterus Journal of Endocrinology 68 121-126

Cheng SV, MacDonald BS, Clark BF and Pollard JW (1985) Cell growth and cell proliferation may be dissociated in the mouse uterine luminal epithelium treated with female sex steroids Experimental Cell Research 160 459-470 
Clark KE, Farley DB, Van Orden DE and Brody MJ (1977) Estrogen-induced uterine hyperemia and edema persist during histamine receptor blockade Proceedings of the Society for Experimental Biology and Medicine 156 411-416

Cocchiara R, Albeggiani G, Di Trapani G, Azzolina A, Lampiasi N, Rizzo F, Diotallevi L, Gianaroli L and Geraci D (1992) Oestradiol enhances in vitro the histamine release induced by embryonic histamine-releasing factor (EHRF) from uterine mast cells Human Reproduction 7 1036-1041

Cook RT and Aikawa M (1973) The effects of heparin on endogenous DNA polymerase activity of rat liver nuclei and chromatin fractions Experimental Cell Research 78 257-270

Drudy L, Sheppard B and Bonnar J (1991) Mast cells in the normal uterus and in dysfunctional uterine bleeding European Journal of Obstetrics and Gynecology and Reproductive Biology 39 193-201

Evans G, Gibson DFC, Roberts SA, Hind TM and Potten CS (1990) Proliferative changes in the genital tissue of female mice during the oestrous cycle Cell and Tissue Kinetics 23 619-635

Fisher R and Blumental T (1982) Analysis of RNA polymerase by trypsin cleavage. Different structural changes produced by heparin and DNA Journal of Biological Chemistry 257 1702-1704

Galand P and de Maertelaer V (1992) Models of oestrogen action: a cell kineticist's view Epithelial Cell Biology 1 177-188

Gibbons AF and Chang MC (1972) Number of mast cells in the rat uterus with special reference to its relation to hormonal treatment and decidual response Biology of Reproduction 6 193-203

Gosden RG, Huntley JF, Douglas A, Inglis L and Miller HR (1993) Quantitative and cytochemical studies of mast cell proteases in rat ovaries and uteri in various reproductive states Journal of Reproduction and Fertility 98 577-582

Goyal RK and Verma SC (1982) Mechanism of action of histamine in the estrogen-primed rat uterus European Journal of Pharmacology 77 2.37-242

Gunin AG (1989) Histamine distribution in the uterine structures of ovariectomized rats administered estradiol, histamine antagonists and an inhibitor of prostaglandin synthesis Arkhiv Anatomii, Gistologii i Embriologii 97 82-86

Gunin A (1996) The role of prolactin in realization of estradiol action in the uterus of ovariectomized rats European Journal of Obstetrics and Gynecology and Reproductive Biology 64 119-127

Gunin A (1997) Effect of heparin on oestradiol-induced cell growth and proliferation in the uterus of ovariectomized rats Journal of Endocrinology $\mathbf{1 5 4}$ $441-448$

Hine RJ, Orsini MW and Hegstrand LR (1985) Changes in tissue histamine during the estrous cycle, pregnancy and pseudopregnancy in the golden hamster Proceedings of the Society for Experimental Biology and Medicine $\mathbf{1 7 9}$ $271-278$

Huang J, Roby KF, Pace JL, Russell SW and Hunt JS (1995) Cellular localization and hormonal regulation of inducible nitric oxide synthase in cycling mouse uterus Journal of Lenkocyfe Biology 57 27-35

Iversen $\mathrm{OH}$ (1964) The influence of estrogenic and androgenic hormones on mast cells and connective tissue in uterus of guinea pig Acta Pathologica et Microbiologica Scandinavica 56 245-252

Janssens JP, Billiet Gr Bonte J and De Loecker W (1983) Independent regulation of growth and steroid receptors in uterus and mammary tumors of rats Anticancer Research 3 385-391

Jeziorska M, Salamonsen L and Wooley D (1995) Mast cell and eosinophil distribution and activation in human endometrium throughout the menstrual cycle Biology of Reproduction 53 312-320

Josefsson B (1968) Studies on eosinophil granulocytes. V. Evidence against the role of histamine as a mediator of eosinophilia in the uterus of the rat Acta Endocrinologica (Copenhagen) 58 532-536

Lavia LA, Roberts DK, Walker NJ and Anderson K (1985) Rat luminal cell nuclear area changes correlated with uterine growth responses induced by a low dose infusion or injection of estradiol-17 beta Steroids 45 519-537

McKercher TC, Van Orden LSd, Bhatnagar RK and Burke JP (1973) Estrogeninduced biogenic amine reduction in rat uterus Journal of Pharmacology and Experimental Therapy 185 514-522

Maraspin LE and Bo WJ (1971) Effects of hormones, pregnancy and pseudopregnancy on the mast cell count in the rat uterus Life Sciences I 10 111-120

Marshall $K$ and Senior $\mathfrak{J}$ (1986) The effect of mepyramine and ranitidine on the oestrogen and anti-oestrogen stimulated rat uterus British Journal of Pharmacology $89251-256$
Martin L, Finn CA and Trinder G (1973) Hypertrophy and hyperplasia in the mouse uterus after oestrogen treatment: an autoradiographic study Journal of Endocrinology 56 133-144

Mohla S and Prasad MRN (1969) Effect of clomiphene and compound $48 / 80$ on uterine glycogen in the rat Fertility and Sterility 20 654-660

Molinari AM, Medici N, Moncharmont B and Puca GA (1977) Estradiol receptor of calf uterus: interactions with heparin-agarose and purification Proceedings of the National Academy of Sciences of the USA 74 4.886-4890

Murray MK (1992) The effect of estrogen and progesterone on structural changes in the uterine glandular epithelium of the ovariectomized sheep Biology of Reproduction 47 408-417

O'Malley B and Means AR (1974) Female steroid hormones and target cell nuclei Science 183 610-620

Padilla L, Reinicke K, Montesino H, Villena FA, Cruz M and Rudolph MI (1990) Histamine content and mast cells distribution in the mouse uterus: the effect of sexual hormones, gestation and labor Cellular and Molecular Biology 36 93-100

Pankova TG, Igonina TM and Salganik RI (1985) Role of histamine as an intermediary in the action of estradiol on the rat uterus: inhibition of the hormonal induction of enzymes using histamine antagonists Problemi Endokrinologii (Moscow) 31 73-78

Popova LA (1989) Effect of ovarian hormones on mast cells in the denervated uterus of rats Fiziologicheskii Zhurnal (Kiev) 35 75-80

Quarmby VE and Korach KS (1984) The influence of 17 beta-estradiol on patterns of cell division in the uterus Endocrinology 114 694-702

Rumpel E, Michna H and Kuhnel W (1995) PCNA-immunoreactivity in the uterus of rats after treatment with the antiestrogen tamoxifen Anatomisher Anzeiger 177 133-138

Sawtell RM, Rew DA, Stradling RN and Wilson GD (1995) Pan cycle expression of proliferating cell nuclear antigen in human colorectal cancer and its proliferative correlations Cytometry 22 190-199

Spaziani E (1963) Relationship between early vascular responses and growth in the rat uterus: stimulation of cell division by estradiol and vasodilatating amines Endocrinology 72 180-191

Szego CM (1965) Role of histamine in mediation of hormone action Federation Proceedings. Federation of American Societies for Experimental Biology $241343-$ 1352

Tainsh KR, Lau HY, Liu WL and Pearce FL (1991) The human skin mast cell: a comparison with the human lung cell and a novel mast cell type, the uterine mast cell Agents and Actions 33 16-19

Terada N, Yamane T, Matsumoto K, Asai H and Kitamura Y (1985) Estrogeninduced increase in eosinophil number and peroxidase activity in uterus of genetically mast cell-deficient W/WV mice Biology of Reproduction 33 899901

Tong IH, Layne DS, Dostaler S and Williamson DG (1983) Comparative studies of the 17 beta-estradiol receptors in rabbit liver, kidney and uterus Journal of Steroid Biochemistry and Molecular Biology 18 273-279

Wang XN, Das SK, Damm D, Klagsbrun M, Abraham JA and Dey SK (1994) Differential regulation of heparin-binding epidermal growth factor-like growth factor in the adult ovariectomized mouse uterus by progesterone and estrogen Endocrinology 135 1264-1271

Westin B (1955) The influence of some ovarian hormones on the occurrence of mast cells in the mouse uterus Acta Pathologica et Microbiologica Scandinavica $36337-342$

Woods AL, Hall PA, Shepherd NA, Hanby AM, Waseem NH, Lane DP and Levison DA (1991) The assessment of proliferating cell nuclear antigen (PCNA) immunostaining in primary gastrointestinal lymphomas and its relationship to histological grade, $\mathrm{S}+\mathrm{G} 2+\mathrm{M}$ phase fraction (flow cytometric analysis) and prognosis Histopathology $1921-27$

Wordinger RJ, Orr EL, Pace K, Oakford L and Morrill A (1985) An assessment of mast-cell deficient mice (W/Wv) as a model system to study the role of histamine in implantation and deciduoma formation Journal of Reproduction and Fertility 73 45I-456

Zhang Z, Funk C, Roy D, Glasser S and Mulholland J (1994) Heparin-binding epidermal growth factor-like growth factor is differentially regulated by progesterone and estradiol in rat uterine epithelial and stromal cells Endocrinology 134 1089-1094 